\title{
HUBUNGAN MOTIVASI BELAJAR DAN KEAKTIFAN DALAM ORGANISASI TERHADAP HASIL BELAJAR SISWA (STUDI KASUS: KELAS XI SMAN 2 KUTA)
}

\author{
Eka Virgia Purwanti ${ }^{\S 1}$, Desak Putu Eka Nilakusmawati ${ }^{2}$, Ni Made Asih ${ }^{3}$ \\ ${ }^{1}$ Program Studi Matematika,Fakultas MIPA - Universitas Udayana[Email:ekavirgia27@gmail.com] \\ ${ }^{2}$ Program Studi Matematika,Fakultas MIPA - Universitas Udayana[Email:nilakusmawati@unud.ac.id] \\ ${ }^{3}$ Program Studi Matematika,Fakultas MIPA - Universitas Udayana[Email:asihmath77@gmail.com] \\ ${ }^{\S}$ Corresponding Author
}

\begin{abstract}
The success of student learning is influenced by several factors such as learning motivation and student activeness in the organization. Each factors has several indicators. This research aims to see the relationship of learning motivation and activeness in the organization of learning outcomes, as well as to know indicators have the greatest real impact. The data used is the primary data in the form of questionnaires distributed, and secondary data in the form of the results of student report cards grade XI IPA academic year 2016/2017 in SMAN 2 Kuta. The research method used to process the data using Canonical Correlation Analysis. The results showed that the factors of learning motivation have a real effect of 0.00000000 on student learning outcomes with the closeness of the relationship of 0.7462935. While the activeness in the organization does not have a real effect on learning outcomes. Passion and desire are the indicators of learning motivation which have the greatest influence among the other indicators with the closeness of the relationship of 0.5798190.
\end{abstract}

Keywords : Activeness in the organization,Canonical Correlation Analysis, Learning Motivation.

\section{PENDAhULUAN}

Pendidikan merupakan suatu wadah dalam proses pengembangan diri manusia. Pendidikan berperan aktif dalam membangun karakteristik dan pola pikir seseorang. Sekolah merupakan salah satu lembaga yang menjalankan pendidikan di negara ini. Dalam suatu pendidikan tujuan utama yang ingin dicapai adalah prestasi hasil belajar.

Prestasi hasil belajar merupakan faktor penting dari tujuan pendidikan terutama pendidikan formal. Purwanto (2002) mengatakan bahwa keberhasilan siswa dalam belajar dipengaruhi oleh dua faktor. Pertama faktor internal yang berasal dari dalam diri siswa, yaitu kondisi jasmani dan rohani yang meliputi kesehatan, intelejensi, sikap, bakat, minat, dan motivasi. Sedangkan faktor kedua adalah faktor eksternal yang berasal dari luar diri siswa, yaitu lingkungan keluarga, lingkungan sekolah, dan lingkungan masyarakat.
Tinggi rendahnya motivasi siswa dalam belajar sangat memengaruhi hasil yang akan dicapai oleh seorang siswa. Agar mampu menguasai setiap pelajaran yang diberikan disekolah,maka para pengajar serta orang tua sangat diharapkan dapat membantu mengembangkan motivasi belajar para siswa sehingga mampu menciptakan hasil belajar yang maksimal. Kegiatan yang dilaksanakan di lingkungan sekolah sangat berpengaruh dalam menunjang proses belajar para siswa. Misalnya organisasi yang ada di lingkungan sekolah maupun yang berhubungan dengan kegiatan di sekolah. Keikutsertaan siswa dalam kegiatan yang dilaksanakan di lingkungan sekolah maupun luar sekolah sangat memengaruhi proses belajar. Organisasi merupakan kumpulan beberapa orang dalam suatu kelompok yang terstruktur dan sistematis. Keaktifan siswa dalam kegiatan organisasi turut mempengaruhi 
proses belajar seorang siswa terutama di sekolah. Hal ini berkaitan dengan cara siswa berinteraksi dengan siswa lain, menumbuhkan rasa tanggung jawab, serta bagaimana kemampuan seorang siswa dalam memecahkan permasalahan yang terjadi di dalam organisasi maupun lingkungannya.

Penelitian sebelumnya oleh Rimayati (2010) menyimpulkan bahwa faktor-faktor yang memengaruhi motivasi belajar memiliki hubungan yang erat dengan prestasi belajar mahasiswa dengan korelasi sebesar 0,718. Sementara penelitian oleh Mertayasa (2011) menyimpulkan bahwa terdapat hubungan yang signifikan di antara latar belakang sosial ekonomi keluarga, keaktifan dalam organisasi, dan motivasi belajar terhadap hasil belajar mahasiswa.

Tujuan penelitian ini adalah: (1) Mengetahui nilai korelasi hubungan antara motivasi belajar dan keaktifan dalam organisasi terhadap hasil belajar siswa; (2) Mengetahui indikator yang memberikan nilai korelasi terbesar.

\section{METODE PENELITIAN}

Data yang digunakan dalam penelitian ini merupakan data primer dan data sekunder. Data primer berupa data hasil kuesioner yang telah disebarkan pada siswa kelas XI IPA di SMAN 2 Kuta, sedangkan data sekunder yang digunakan berupa nilai raport para siswa pada kelas XI IPA Tahun ajaran 2016/2017 di SMAN 2 Kuta. Sampel dalam penelitian ini adalah siswa kelas XI IPA di SMAN 2 Kuta yang aktif sebagai pelajar pada periode mei hingga september tahun ajaran 2016/2017 dari keseluruhan siswa kelas XI di SMAN 2 Kuta. Teknik pengambilan sampel yang digunakan dalam penelitian ini adalah metode Purposive sampling. Purposive sampling digunakan jika peneliti mempunyai pertimbangan-pertimbangan tertentu di dalam pengambilan sampel untuk tujuan tertentu (Riduwan, 2004). Sampel yang digunakan dalam penelitian ini adalah 162 siswa (responden) kelas XI IPA dari keseluruhan siswa di SMAN 2
Kuta, dimana berdasarkan pertimbangan peneliti kelas XI merupakan siswa yang tidak mengikuti organisasi yang diwajibkanoleh sekolah dan kelas XI IPA merupakan siswa yang memiliki motivasi belajar tinggi. Dilakukan uji validitas dan reliabilitas terhadap data yang diperoleh dengan program SPSS, kemudian di analisis menggunakan metode Analisis Korelasi Kanonik untuk menggambarkan jumlah dan sifat hubungan saling independen yang ada diantara dua himpunan variabel (Pituch \& Stevens, 2016). Program STATISTICA versi 12 digunakan dalam mengolah data untuk melihat hubungan antara motivasi belajar dan keaktifan dalam organisasi terhadap hasil belajar, serta hubungannya dengan masing-masing indikator penyusun.

\section{HASIL DAN PEMBAHASAN}

\subsection{Deskripsi Data}

Pada penelitian ini data primer yang dipergunakan mencakup data hasil kuesioner yang telah disebarkan berisi 37 item pertanyaan, dimana 18 item pertanyaan berhubungan dengan motivasi belajar dan 19 item pertanyaan berhubungan dengan keaktifan siswa dalam organisasi. Sedangkan data sekunder yang digunakan untuk penelitian berupa nilai raport para siswa pada kelas XI IPA Tahun ajaran 2016/2017 di SMAN 2 Kuta. Terdapat lima kelas yang terdiri dari kelas XI IPA1 sebanyak 31 siswa, XI IPA2 sebanyak 33 siswa, XI IPA3 sebanyak 33 siswa, XI IPA4 sebanyak 35 siswa, dan XI IPA5 sebanyak 30 siswa. Total keseluruhan siswa pada kelas XI IPA di SMAN 2 Kuta adalah 162 siswa.

$$
\begin{aligned}
& =\frac{0,386 \sqrt{30-2}}{\sqrt{1-0,386^{2}}} \\
& =\frac{0,386(5,29150)}{\sqrt{1-0,148996}} \\
& =\frac{2,0425}{0,9224} \\
& =2,214
\end{aligned}
$$




\subsection{Uji Validitas dan Reliabilitas Kuesioner}

Untuk menguji validitas dan reliabilitas kuesioner maka di lakukan penyebaran kuesioner secara acak kepada 30 siswa sebagai responden pada kelas XI IPA Tahun ajaran 2016/2017 di SMAN 2 KUTA. Pengujian data hasil penyebaran kuesioner diolah dengan menggunakan uji validitas dan reliabilitas pada program SPSS Statistics 22.

Uji validitas dilakukan dengan perbandingan nilai $t_{\text {hitung }}$ dengan nilai $t_{\text {tabel }}$. Apabila nilai $t_{\text {hitung }}$ data hasil kuesioner lebih besar dari nilai $t_{\text {tabel }}$, maka data tersebut dikatakan valid, sebaliknya apabila nilai $t_{\text {hitung }}$ data hasil kuesioner lebih kecil dari nilai $t_{\text {tabel }}$ maka di katakan tidak valid.

Hasil uji validitas data item pertanyaan No.1 dari 30 responden dengan menggunakan program SPSS maka di dapatkan nilai korelasi pearson(r) yaitu sebesar 0,386 sehingga hasil nilai $t_{\text {hitung }}$ data item pertanyaan no.1 adalah sebagai berikut :

$$
t_{\text {hitung }}=\frac{r \sqrt{n-2}}{\sqrt{1-r^{2}}}
$$

Dari hasil Uji validitas 37 item pertanyaan pada kuesioner didapatkan bahwa keseluruhan item pertanyaan bersifat valid.

Hal ini dapat ditunjukkan dengan perbandingan nilai $t_{\text {hitung }}$ lebih besar dari nilai $\mathrm{t}_{\text {tabel }} 1,701$ dimana $\mathrm{n}=30$ dan derajat bebas $\mathrm{n}$ $2(\mathrm{db}=28)$.

Tabel 1. Uji Reliabilitas Kuesioner

\begin{tabular}{|r|r|r|}
\multicolumn{3}{|c|}{ Reliability Statistics } \\
\begin{tabular}{|c|c|} 
Cronbach's \\
Alpha
\end{tabular} & $\begin{array}{c}\text { Cronbach's } \\
\text { Alpha Based on } \\
\text { Standardized } \\
\text { Items }\end{array}$ & N of Items \\
\hline .920 & .925 & 37 \\
\hline
\end{tabular}

Hasil analisis reliabilitas kuesioner dapat dilihat pada Tabel 1 dimana hasil uji reliabilitas kuesioner dengan nilai $r$ Alpha Cronbach's sebesar 0,920 menunjukkan nilai lebih besar dari 0,6 sehingga kuesioner yang digunakan untuk penelitian bersifat reliabel.

\subsection{Uji Signifikan Nilai Korelasi}

Uji signifikan analisis korelasi kanonik dilakukan dengan melihat perbandingan antara Pvalue dan nilai taraf nyata $(\alpha)$ sebesar 0,05 . Nilai dapat dikatakan signifikan jika $P$-value lebih kecil dari taraf nyata $(\alpha)$.

Tabel 2. Uji Signifikan Nilai Korelasi Antara Faktor terhadap Hasil Belajar

\begin{tabular}{|l|c|c|}
\hline $\begin{array}{c}\text { Hubungan Faktor } \\
\text { dengan Hasil Belajar }\end{array}$ & $\begin{array}{c}\text { Nilai } \\
\text { Korelasi }\end{array}$ & $P$-value \\
\hline Motivasi Belajar & 0,7462935 & 0,0000000 \\
\hline $\begin{array}{l}\text { Keaktifan dalam } \\
\text { organisasi }\end{array}$ & 0,5278031 & 0,7113795 \\
\hline \multicolumn{2}{|l}{ Sumber: Data diolah, 2018 } \\
\hline
\end{tabular}

Hasil uji signifikan korelasi kanonik pada Tabel 2 menggunakan program Statistica versi 12 menunjukkan bahwa terdapat hubungan yang signifikan antara variabel motivasi belajar dengan hasil belajar. Hal ini dapat dilihat dari nilai $P$-value faktor motivasi belajar yaitu sebesar 0,000000 dengan nilai korelasi 0,7462935. Sedangkan pada faktor keaktifan dalam organisasi menunjukkan hubungan yang tidak signifikan dengan hasil belajar dilihat dari nilai $P$-value sebesar 0,7113795 dengan nilai korelasi 0,5278031. Maka dapat dikatakan bahwa faktor keaktifan dalam organisasi tidak memiliki hubungan yang signifikan dengan hasil belajar, sementara faktor motivasi belajar memiliki keeratan hubungan yang signifikan terhadap hasil belajar. Dari hasil uji signifikan tersebut dapat dilihat bahwa indikator-indikator penyusun yang memiliki hubungan signifikan terhadap hasil belajar adalah indikator penyusun motivasi belajar. 
Tabel 3. Uji Signifikan Nilai Korelasi Antara Indikator Penyusun Motivasi Belajar terhadap Hasil Belajar

\begin{tabular}{|l|l|l|}
\hline $\begin{array}{l}\text { Indikator Penyusun } \\
\text { Motivasi Belajar } \\
\text { dengan Hasil Belajar }\end{array}$ & $\begin{array}{l}\text { Nilai } \\
\text { Korelasi }\end{array}$ & P-value \\
\hline Hasrat dan Keinginan & 0,5798190 & 0,0000319 \\
\hline $\begin{array}{l}\text { Dorongan dan } \\
\text { Kebutuhan }\end{array}$ & 0,4208051 & 0,0071909 \\
\hline Harapan dan Cita-cita & 0,4903542 & 0,0003025 \\
\hline $\begin{array}{l}\text { Penghargaan dan } \\
\text { Penghormatan }\end{array}$ & 0,3009226 & 0,8143920 \\
\hline Lingkungan yang Baik & 0,4460462 & 0,0993900 \\
\hline Kegiatan yang Menarik & 0,5618084 & 0,0000030 \\
\hline & & \\
\hline
\end{tabular}

Sumber: data diolah, 2018

Hasil uji signifikan nilai analisis korelasi kanonik pada Tabel 2 menunjukkan bahwa pada indikator penghargaan dan penghormatan dengan nilai $P$-value sebesar 0,8143920 dan indikator lingkungan yang baik dengan $P$ value sebesar 0,0993900 tidak memiliki hubungan yang signifikan terhadap hasil belajar. Sedangkan indikator hasrat dan keinginan dengan $P$-value sebesar 0,0000319 merupakan indikator yang memiliki pengaruh paling besar dibandingkan dengan indikatorindikator lain terhadap hasil belajar dengan nilai korelasi sebesar 0,5798190.

\subsection{Interpretasi Hasil Korelasi Kanonik}

Dari penjabaran hasil uji signifikan nilai korelasi antara motivasi belajar dan keaktifan dalam organisasi terhadap hasil belajar dapat dilihat bahwa keaktifan dalam organisasi tidak memiliki nilai korelasi yang signifikan terhadap hasil belajar. Dalam hal ini, hasil uji tersebut menjelaskan bahwa keikutsertaan siswa dalam organisasi formal maupun nonformal baik di sekolah maupun di luar sekolah tidak memiliki pengaruh yang nyata terhadap hasil belajar yang diperoleh, baik dalam segi frekuensi kegiatan yang diikuti, posisi siswa dalam organisasi, interaksi siswa dengan anggota lain di dalam organisasi, tanggung jawab dan loyalitas siswa, serta dukungan orang tua/wali pada siswa dalam mengikuti kegiatan organisasi.
Dari hasil uji signifikan nilai korelasi antara motivasi belajar terhadap hasil belajar memiliki hubungan yang signifikan dan pengaruh yang nyata terhadap hasil belajar. Hal ini dapat dikatakan bahwa hasil belajar siswa pada kelas XI IPA di SMAN 2 Kuta dipengaruhi oleh motivasi belajar para siswa, sedangkan keaktifan siswa dalam organisasi yang mereka ikuti tidak mempengaruhi hasil belajar. Dilihat dari nilai korelasi motivasi belajar siswa sebesar 0,7462935 dapat di ketahui bahwa motivasi belajar sangat berpengaruh secara nyata terhadap hasil belajar, dimana semakin tinggi motivasi belajar seorang siswa maka semakin tinggi nilai hasil belajarnya.

Dapat diketahui indikator-indikator penyusun motivasi belajar antara lain adalah hasrat dan keinginan, dorongan dan kebutuhan, harapan dan cita-cita, penghargaan dan penghormatan, lingkungan yang baik, serta kegiatan yang menarik. Dari penjabaran hasil uji nilai signifikan nilai korelasi antara indikator penyusun motivasi belajar terhadap hasil belajar dapat dilihat bahwa diantara enam indikator, hanya empat indikator yang memiliki hubungan signifikan. Keempat indikator tersebut yaitu, hasrat dan keinginan, dorongan dan kebutuhan, harapan dan citacita, serta kegiatan yang menarik.

Hasil uji signifikan nilai korelasi antara indikator hasrat dan keinginan terhadap hasil belajar adalah sebesar 0,5798190 dengan $P$ value 0,0000319 . Hal ini menjelaskan bahwa hasrat dan keinginan berpengaruh nyata terhadap hasil belajar seorang siswa, dimana semakin tinggi hasrat dan keinginan seorang siswa untuk belajar, maka semakin tinggi hasil belajar yang diperoleh. Dari hasil penelitian, dapat dilihat bahwa para siswa secara aktif terdorong untuk bertanya kepada guru ketika mereka belum memahami materi yang dipelajari. Untuk hasil uji signifikan nilai korelasi antara indikator dorongan dan kebutuhan dapat dilihat yaitu sebesar 0,4208051 dengan P-value 0,0071909. Sehingga dorongan dan kebutuhan siwa untuk belajar merupakan salah satu indikator yang 
secara nyata mempengaruhi hasil belajar. Dorongan dari orang tua untuk selalu mengingatkan anaknya belajar sangat membantu dalam mendisiplinkan siswa untuk belajar dengan rajin dan tekun.

Dari hasil uji signifikan nilai korelasi antara indikator harapan dan cita-cita yaitu sebesar 0,4903542 dengan $P$-value 0,0003025. Hal ini memperlihatkan bahwa indikator harapan dan cita-cita memiliki pengaruh dalam keberhasilan belajar seorang siswa. Siswa yang akan menjalani UAS tentu akan mengharapkan hasil nilai yang bagus, oleh karena itu seorang siswa akan berusaha belajar dengan giat agar bisa mencapai nilai yang diinginkan.

Dari hasil pengujian nilai signifikan nilai korelasi antara indikator kegiatan yang menarik terhadap hasil belajar dapat dilihat bahwa indikator tersebut memiliki pengaruh yang nyata sebesar 0,5618084 dengan $P$-value 0,0000030 .

Hal ini berkaitan dimana dalam proses belajar mengajar guru diharapkan untuk mampu berpartisipasi membangun suasana yang mampu meningkatkan motivasi belajar siswa, misalnya melalui kegiatan yang menarik seperti kerja kelompok, latihan soal, tanya jawab, diskusi, maupun kegiatan lain dalam mendukung proses belajar siswa di kelas.

Pada hasil uji signifikan nilai korelasi terdapat indikator yang tidak memiliki hubungan yang signifikan terhadap hasil belajar, antara lain penghormatan dan penghargaan serta lingkugan yang baik.

Dari hasil uji signifikan indikator penghargaan dan penghormatan memiliki nilai korelasi sebesar 0,3009226 dengan $P$-value sebesar 0,8143920. Hal ini menunjukkan bahwa indikator penghargaan dan penghormatan tidak memiliki pengaruh yang nyata terhadap hasil belajar. Para siswa termotivasi untuk belajar demi mendapatkan nilai yang baik bukan di dasarkan pada imbalan atau hadiah yang akan diberikan oleh orang tua, hal ini dikarenakan tidak semua orang tua menerapkan pemberian imbalan atau hadiah untuk anaknya demi meningkatkan hasil belajar atau mencapai nilai yang tinggi pada hasil belajar.

Pada indikator lingkungan yang baik diperoleh nilai korelasi sebesar 0,4460462 dengan $P$-value 0,0993900 , hal ini menunjukkan bahwa indikator lingkungan yang baik tidak memiliki pengaruh yang nyata terhadap hasil belajar. Hal ini berkaitan dengan sarana dan prasarana penunjang kegiatan belajar para siswa baik di sekolah maupun di rumah. Ketersediaan sarana dan prasarana belajar untuk para siswa terutama di rumah seperti meja belajar, komputer, serta peralatan lainnya tidak mempengaruhi motivasi siswa untuk rajin belajar dalam mencapai hasil yang maksimal. Dengan keterbatasan sarana dan prasarana yang dimiliki siswa di rumah tidak mempengaruhi para siswa untuk tekun dan rajin belajar sehingga mampu meraih nilai hasil belajar yang maksimal.

\section{KESIMPULAN DAN SARAN}

Berdasarkan analisis dan pembahasan dari penelitian yang dilaksanakan, maka dapat disimpulkan bahwa hasil penelitian pada siswa kelas XI IPA di SMAN 2 Kuta menunjukkan adanya pengaruh yang nyata antara faktor motivasi belajar terhadap hasil belajar siswa dengan nilai korelasi sebesar 0,7462935. Sedangkan faktor keikutsertaan siswa dalam organisasi tidak memiliki pengaruh yang nyata terhadap hasil belajar dengan nilai korelasi sebesar 0,5278031.

Pada hasil penelitian nilai korelasi antara indikator-indikator penyusun motivasi belajar terhadap hasil belajar siswa menunjukkan bahwa indikator hasrat dan keinginan memiliki nilai korelasi paling besar dari seluruh indikator. Hal ini menunjukkan bahwa indikator hasrat dan keinginan memiliki pengaruh nyata yang paling besar dibandingkan indikator lainnya

Saran yang dapat diberikan berdasarkan hasil penelitian pada siswa kelas XI IPA di SMAN 2 Kuta untuk meningkatkan kualitas 
hasil belajar siswa maka motivasi belajar siswa harus terus dikembangkan supaya memiliki potensi yang baik kedepannya untuk mencapai prestasi belajar para siswa secara maksimal. Untuk penelitian diperlukan penambahan variabel agar hasil penelitian lebih akurat, misalnya variabel latar belakang sosial dan ekonomi keluarga, variabel lingkungan sekolah meliputi sarana dan prasarana, variabel tingkat kecerdasan (IQ), dan beberapa variabel lainnya.

\section{DAFTAR PUSTAKA}

Mertayasa, I Putu. 2011. "Analisis Korelasi Kanonik untuk Melihat Hubungan Hasil Belajar Dengan Latar Belakang Sosial Ekonomi Keluarga, Keaktifan dalam Organisasi, dan Motivasi Belajar". Skripsi. Jurusan Matematika FMIPA Universitas Udayana.

Pituch, Keenan A. dan James P.Stevens. 2016. Applied Multivariate Statistics for The Social Sciences. Routledge. New York.

Purwanto, Ngalim. 2014. Psikologi Pendidikan. PT. Remaja Rosdakarya. Bandung.

Riduwan. 2004. Metode dan Teknik Menyusun Tesis. Alfabeta. Bandung.

Rimayati, Ni Wayan. 2010. "Hubungan Faktor-Faktor yang Mempengaruhi Motivasi dengan Prestasi Belajar Mahasiswa". Skripsi. Jurusan Matematika FMIPA Universitas Udayana.. 